\title{
Rock Critics as 'Mouldy Modernists'
}

\author{
Becky Shepherd, Macquarie University
}

Three particularly prevalent questions determine the focus of this study. First, why does rock criticism continue to tie itself to the past? Second, why does contemporary popular culture, of which the specialist music press is a principal cultural intermediary, propagate a fixation with canonical rock music and the narrative tropes of nostalgia and authenticity that surround the canon and its popular cultural significance? Third, how does the specialist music press generate retrospectivity in contemporary popular culture? There are several conceptual platforms from which to view and critique the continued maintenance of the rock canon and the general preoccupation with the past held by the specialist music press. I engage in this essay with these conceptual considerations, while also providing an historical and theoretical overview of the canon, and critiquing, in particular, rock criticism's role in the creation of the canon as the centre of a 'rock world' (Frith 1988: 2).

\section{Retrospectivity and the lineage of new journalism}

The new journalism of the late 1960s almost single-handedly crafted the notion of a rock canon. This same hierarchical understanding of 'rock versus pop' music continues to characterise the vast majority of contemporary journalistic writing on popular music. While there has been much scholarly discussion surrounding a recent decline in the 
consumption of music press publications (Laing 2006), of the existing modes of discourse on popular music - including the internet, radio, film and television - the contemporary specialist music press still operates as a 'cultural intermediary' (Bourdieu 1984) or 'gatekeeper' (Toynbee 1993: 290; Shuker 1998: 199) between the music industry, its consumers and fans of popular music. In contemporary popular culture, the specialist music press appear to maintain significance by propagating retrospectivity, and maintaining the 'myth of rock's own ideological effects' (Frith 2004: 35), which positions pop and rock music as binary opposites. The press maintains avid interest in canonical artists, thereby sustaining the valorisation of the rock canon. Furthermore, the press champions new 'retro' sounding rock music, comparing the sound of this 'new' music with those older works consecrated within the canon.

The discursive tropes of authenticity and nostalgia frame the function and value of this retrospectivity, illustrated not only in the specialist music press, but throughout contemporary popular culture. More recently, EMI's vinyl reissues of canonical albums (2008), Martin Scorsese's live concert footage of The Rolling Stones in Shine A Light (2008), The Beatles Remasters (2009), The Who's Quadrophenia tour (2012), and the popularity of reissue guitars, amplifiers, keyboards and analogue audio technologies, for example, further proliferate the popularity of all things 'retro' in contemporary popular culture. This preoccupation with the past maintains rock music's belief in its own supremacy over all other constituent genres of popular music.

As a means of fuelling this rhetoric of nostalgia, and maintaining the supremacy of 'classic' or canonical rock music, the press uses two particularly ubiquitous approaches. First, the press use a series of nostalgic markers to develop catchy terminology and genre titles to describe and categorise the sound of emerging contemporary 'retro' rock music. Critics writing for the contemporary music press make frequent reference to canonical music in their descriptive commentary of album reviews, interviews and critiques of new 'retro' music, and its contemporary referents. The music press creates direct parallels between the sound of new emerging 'retro' music, including artists such as The White Stripes, Midlake and Wolfmother, with the sounds of canonical rock music, furthermore attributing a type of cultural capital, directly characterised by artistic credibility and notions of authenticity, to these new rock releases. These markers include references to retrospective forms such as garage rock, psychedelia, progressive 
rock and punk. Accompanying these titles are terms such as 'nu' (Wooldridge 2005: 14) 'throwback' (Hampton 2007: 56) and 'vintage' (Male 2002: 82). This combination of terms, like for example 'nu-metal,' characterise specific types of new rock music with a type of nostalgic loading. This loading works concurrently with the culturally laden tropes of authenticity and artistic credibility already characterising terms such as progressive rock, metal and psychedelia for example. So paradoxically, that which appears to be new also carries the label vintage' or 'retro.'

Secondly, the contemporary specialist music press generate countless 'best-of' critics and readers' polls, all of which overwhelmingly valorise pre-1980s rock music. A recent study of 'best-of' polls selected from five of the most popularly circulated music publications of the last decade-SPIN, Rolling Stone, MOJO, Q and Classic Rockdemonstrates the maintenance of this dominate nostalgia for canonical rock music. Artists including Led Zeppelin, The Beatles, The Who, The Rolling Stones, Pink Floyd and David Bowie, for example, appear on all five of the 'best-of' lists from these magazines, and are credited for more than one recording or performance. 88 percent of the artists featured collectively across all five lists represent music recorded and released prior to 1980. This process of 'recanonisaton' is a continuation of the pivotal role that the press, and critics of the music press, have always played in the crafting of the hierarchical ideology that characterises the 'pop versus rock music' schism.

During the late 1960s the rise of publications such as Crawdaddy, Rolling Stone, and Creem magazine, and some key contributors, such as Lester Bangs, Robert Christgau and Nat Hentoff, began to construct the foundations of a type of 'rock world' (Frith 1988: 2), out of which emerged a 'myth of rock's own ideological effects' (Frith 2004: 35 ), or an ascribed authenticity that came to typify certain types of music consecrated within the canon of popular music. Refecting an increasingly self-reflexive popular music market, a new, more critical discourse on popular music would emerge in the form of 'new journalism,' inherent to the aforementioned publications. Buoyed by the emergence of a new counter-cultural sensibility, these publications would go on to play an integral role in the formation of a particular 'art world' or 'rock world.'

The valorisation of this world through various fanzines, specialist and trade publications and the general press played a primary role in the dissemination of a cultural discourse around rock music. During the late 1960s and throughout the 1970s, the music press and 
its contributing critics and editors began to coin new terms and expressions that became associated with the categorisation of musical styles, including the titles of music genres, and the definition of particular music and socio-cultural movements. Collectively these writers performed 'an external evaluation of the music industry's products, based upon certain core assumptions about what makes good, important music, and what makes disposable crap' (Fenster 2002: 86). Such musical and sociocultural commentaries proliferated a discourse that came to characterise the rock world and to orchestrate 'a popular music criticism [that could] be understood as meaning making, a way of continuing the discourse of popular music on a non-musical plane' (Jones \& Featherly 2002: 32). Critics of the new journalism created a discourse of authenticity used to elevate popular musical forms of the late 1960s and 1970s, endowing selected artists and their repertoire - such as Elvis Presley, Bob Dylan, Jimi Hendrix, The Who, The Beatles, Led Zeppelin, the Clash — with both artistic and cultural function and value. Frith explains that this new style of journalism '[was] not so much about representing music to a public as cultivating a "knowing community" that links a select set of musicians to an equally select set of listeners - people who define themselves as superior to the mainstream undiscriminating popular culture' (Firth 1996: 66-67).

With such ideologically generated discourses in place, the specialist music press has a template from which to continually assign set hierarchies in popular music. However, this process of delineation is particularly contentious and, in actuality, bears no absolutes. Therefore, at this point, the most pressing point of inquiry asks why the contemporary music press insists upon maintaining essentially modernist discourses surrounding rock music? Why does the press cling to traditional models of interpretation and presentation as part of a contemporary discourse on popular music?

\section{Modernist narratives and cultural reification}

Retrospectivity is mobilised by a series of nostalgic trends. Firstly, these trends can be observed as a harking back to 'an authentic origin or centre from which to disparage the degenerate present' (Greene 1991: 305), with nostalgia fuelled by hostile reactions to the assumed inadequacies of the present. ${ }^{1}$ Such references to 'authenticity' can be

\footnotetext{
${ }^{1}$ For further studies on the rhetoric of nostalgia as a hostile reaction to the inadequacies of the present, see Stewart (1984) and Williams (1977).
} 
aligned with modernist conceptions of nostalgia as it preferences the maintenance of grand narratives, that is, the canon.

Alternatively, conceptions of nostalgia can be understood as a type of discursive reality, or as Frederick Jameson explains, 'a stylistic museum from which artefacts of the past becomes part of contemporary pastiche' (1985: 113). In a contemporary context, nostalgia is referred to as popular memory, an historical consciousness (Tannock 1995), and a 'structure of feeling' (Williams 1977: 128). Here, nostalgia becomes a gateway to an imagined experience of the past. In this context, nostalgia as a reference to the past can also imply the effacement of grand historic structures such as canonicity. Nostalgia represents a breakdown of such signifiers, a type of dissolution of affect, or a displacement of the aesthetic significance of the rock canon. Put simply, contemporary popular culture poaches from the canon and disregards its cultural significance to denote a contemporary concept of style or history as a style, the elements of which can be rearranged and recontextualised as part of the continued reification of culture.

Nostalgia therefore uses the canon as a type of mass cultural reification, a discursive construction that is itself a commodity, the production and distribution of which standardises mass cultural products, used to homogenise mass culture. In this context, canonical rock music is maintained within the contemporary domain, and rendered significant on account of its commodity value. Jameson furthers these conceptions of commodified canonical nostalgia, by explaining how contemporary popular culture poaches the most unique forms of artistry from the imaginary museum that is conceptualised as 'the past.' While Jameson does not make direct reference to canonical discourses, I suggest that the popular music canon can be conceptualised as part of the 'imaginary museum' (1985: 115), to which he makes reference. Jameson is not denying the existence of a canon, but rather problematising the significance of such a modernist discourse in the contemporary domain. He explains that

\footnotetext{
[t]here is another sense in which writers and artists of the present day will no longer be able to invent new styles and worlds - they've already been invented; only a limited number of combinations are possible; the most unique ones have been already thought ... Hence, once again, pastiche: in a world in which stylistic innovation is no longer possible, all that is left is to imitate dead styles, to speak through the masks and with the voices of the styles of the imaginary museum. (1985: 115)
}

Clearly, Jameson's identification of pastiche as a feature of a suggested 'post modernity' is accurate and evidenced by contemporary popular culture. I do not, 
however, adhere to either his regarding the canon as a 'dead style' or his inference to pastiche as pure similitude. Retrospectivity, while fuelled by the press, spills over into other facets of popular culture to create something 'new,' not as direct repetition, but as a type of difference by means of recontextualsation (new 'retro' rock music, remastered releases). Perhaps therefore the simple concept of this type of recontexualisation negates pointless similitude when we are talking about retrospectivity. If, for example, retrospectivity were only evident in the nostalgic preoccupation of the contemporary music press, that is 'best-of lists and revived feature articles on Bob Dylan, The Beatles and Keith Richards, then we could in fact interpret nostalgia as a longing for the past, or an 'authentic origin,' as would be typically modernist, and acknowledge an obvious thread of similitude and repetition. We could therefore also assume that such a longing can be satisfied by the totality of the canon and Jameson would win the argument. Retrospectivity is, however, more than nostalgia, and nostalgia does not appear to function as a passive longing for the past, but rather as a structure of feeling that functions as a vital ingredient in the production of contemporary pastiche. Suffice to say, while nostalgia can be considered an authentic and necessary reverence for the past, with acknowledgement of the canon as sacred and 'classic,' it can at the same time recharacterise the canon as a type of popular cultural bric-a-brac.

Major record labels for example, engage in this game of rhetoric by acknowledging that remastered versions of canonical albums hold a particular currency, with not only the older generation of original fans, but with the younger generation whose association with canonical rock music is directly framed by the romanticism of imagined nostalgia. The creation and promotion of new 'retro' rock also engages in this game of semantics, paying homage to the canon on the one hand, and poaching shamelessly from it on the other. The motive is therefore two-fold, but the result is the manufacture of something new, whether it be a recontexualisation of canon rock music in the form of new 'retro' music, or the recontextualisation of a recording in the form of a remaster. New 'retro' rock music and remastered releases of canonical albums both demonstrate examples of the duality of retrospectivity as it functions as part of contemporary popular culture. Both represent a type of canonical reification, and yet simultaneously both represent the emergence of 'new' hybridised and recontextualised impressions of the canon and a movement away from pure similitude, demonstrating something borrowed, something recontextualised, and therefore something 'new.' 
When we return to Jameson, then, we acknowledge as salient his observations about canonical nostalgia and cultural reification. However, Jameson appears to be making some slightly redundant claims here, as any revisiting of the past essentially reifies an artefact. Stylistic innovation is always pastiche, and is therefore necessarily part retrospective; new styles are hybrid expressions of what has come before. To make an obvious point, the popular music canon is predominately characterised by rock music, which is a hybridised pastiche of rhythm and blues and country music. Therefore, if Jameson considers imitation and pastiche as similitude then he is indirectly making a more contentious statement on popular music more generally. The point of conjecture, therefore, lies closer to the tried and tested notion of art versus commerce, and therein we can ask: is that the point at which this inevitable process of reification negates artistic progression?

Jameson indirectly and derogatorily suggests that any recontextualisation of the past, represented as the 'imaginary museum,' is necessarily a part of the mass reification of contemporary popular culture: the artistry is redundant; the commodity value is paramount. Jameson, therefore, implies that the canon, as a grand narrative within the imaginary museum, is a discursive construction that maintains narrative claims to its own totality. Moreover, Jameson suggests that capitalist mass culture depends upon such discourses to form a stylistic museum from which contemporary culture can create pastiche (1985: 115). In this context the canon and its constituents become empty signifiers. To consider the canon as merely a collection of de-signified artefacts would be to witness its contemporary reiteration as pure similitude, yet this does not appear to be the case. Rather than functioning as empty signifiers of pastiche within a contemporary context, the canon of rock music, rock music's assertions of authenticity that typify the canon, and the role of the contemporary specialist music press as a champion of retrospectivity, remain a significant part of a popular cultural hierarchy that frames the aesthetics of popular music. So while we cling to modernist narratives, we create difference by poaching from, and recontextualising, the past in a contemporary context.

\section{Conclusion}

Where is contemporary rock criticism situated in all this theorising of the mechanics of nostalgia and retrospectivity? While I have argued here that the retrospective focus is 
not simply a passive romanticisation of the past, the contemporary specialist music press continues to valorise canonical rock music at the peril of other constituent genres of popular music (pop, rap, hip hop, and the many permutations of dance music for example). With the press continuing to operate as a significant cultural intermediary between the music industry, critics, fans and musicians, the dominant discourse on popular music is steeped in nostalgia, and in particular is characterised by a preoccupation with canonical rock music. This is problematic for a number of reasons. The world of sampling, remixes, and mash-ups, and the explosion of MP3 cultures and home production, for example, are undoubtedly signalling as stimulating and progressive a climate change as rock'n'roll once was, and yet those developing contemporary discursive frameworks for these musical expressions of artistry are looking backwards. When they pause for a moment to glimpse the present, they are predominately focussing on that which is characterised by the past. The contemporary music press has somewhat backed itself into a tight corner.

The retrospective focus of the press is therefore not without fault or criticism. However, when we look outside what appears to be the banal reiteration of the specialist music press and its rehashed cover articles on canonical artists, we return to a discussion on the recontextualisation of the canon. Ubiquitous throughout contemporary popular music is a reimagining of the popular music canon, contemporary additions to the canon; derivative ... yes, but perhaps the overarching question remains - isn't everything somehow derivative of that which has come before? When Jameson talks about cultural reification and we apply this notion to our understanding of retrospectivity in the contemporary music press, we are left wondering if retrospectivity as reification necessarily negates artistic validity, and difference?

Perhaps a movement away from this type of stagnation and the preconceived inherent notions of retrospectivity, lies in realigning our presuppositions about contemporary uses of the canon and its surrounding discourses on nostalgia. There are those who feel that nostalgia for canonical rock and by default new 'retro' rock music is a pointless reiteration of modernist discourses. There are those who champion the maintenance of 'authentic' artistry and those who cling to rock's own ideological conceptions of superiority, which are reiterated by the canon. This particular perspective is characterised by an adherence to the totality of the canon as a dominant nostalgic 
discourse in popular music. It is from this perspective that contemporary forms of popular music as seen as 'lesser-than' or inferior to that which has come before, in particular, that which characterises pre-1980s rock music. Then there are those who applaud retrospectivity, but see no sense in simply reiterating the modernist narratives that surround the canon. Rather, these critics, fans, and musicians embrace retrospectivity as one type of reiteration of the canon, in the form of contemporary recontextualisation. Here, all things 'retro' oriented are, therefore, new, borrowed, rebuilt and reflavoured by contemporary popular music. Within that context contemporary retrospectivity and the role of the contemporary music press can realign conceptions about canonical music and its function and 'value' within contemporary popular culture.

However retrospectivity is understood, the specialist music press are firmly tied to the past when it comes to ascribing value judgements about popular music. So how do we move from here? How do we recraft conversations about value in popular music? Do we need to recraft these presuppositions surrounding the canon? How will contemporary rock criticism provide a more progressive engagement with emerging popular music, while self-referentially acknowledging the canon as an ascribed type of nostalgia? As the press remain preoccupied by retrospectivity and the tropes of authenticity and nostalgia that surround the rock canon, are they in fact missing some of the main game as it is being played in contemporary popular culture?

\section{Reference List}

Bourdieu, P. 1984, Distinction: A Social Critique of the Judgment of Taste. Routledge, London \& New York.

Fenster, M. 2002, 'Consumers' Guides: The Political Economy of the Music Press and the Democracy of Critical Discourse,' in The Popular Music Studies Reader, (eds) A. Bennett, B. Shank \& J. Toynbee. Routledge, London \& New York.

Frith, S. 1988, Music For Pleasure: Essays in the Study of Popular Music. Polity Press, Cambridge. 1996, Performing Rights. Harvard University Press, Cambridge, MA. 2004, 'Towards An Aesthetic of Popular Music,' in Popular Music. Critical Concepts in Media and Cultural Studies. Routledge, London \& New York.

Laing, D. 2006, 'Anglo-American Music Journalism: Texts and Contexts,' in The Popular Music Studies Reader (eds) A. Bennett, B. Shank \& J. Toynbee. Routledge, London \& New York.

Jones, S. \& Featherly, K. 2002, 'Re-Viewing Rock Writing: Narrative of Popular Music Criticism,' in Pop Music and the Press, (ed.) S. Jones. Temple University Press, Philadelphia, 19-40.

Jameson, F. 1985, 'Postmodernism and Consumer Culture,' in Postmodernism Culture, (ed.) H. Foster. Pluto Press, London, 111.

Male, A. 2002, 'Basic Instinct.' MOJO, September: 81-88.

Hampton, J. 2007, 'The 40 Best Albums of 2006.' SPIN, January: 56.

Scorsese, M. (dir.) 2008, Shine a Light, documentary, $20^{\text {th }}$ Century Fox. 
Stewart, S. 1984, On Longing: Narratives on the Miniature, the Gigantic, the Souvenir, the Collection. John Hopkins University Press, Baltimore.

Williams, R. 1977, Marxism and Literature. Oxford University Press, Oxford.

Toynbee, J. 1993, 'Policing Bohemia, Pinning up Grunge: The Music Press and Generic Change in British Pop and Rock,' Popular Music, vol. 12, no. 3: 289-300. 